\title{
RANCANG BANGUN APLIKASI MOBILE ANDROID UNTUK SISTEM INFORMASI LOKASI WISATA KABUPATEN GRESIK MENGGUNAKAN METODE ITEM-BASED COLLABORATIVE FILTERING
}

\author{
Hendry Hermawan ${ }^{1)}$, Harunur Rosyid ${ }^{2)}$ \\ 1) PT Petrokimia Gresik \\ 2) Teknik Informatika Universitas Muhammadiyah Gresik \\ E-mail: hendryhermawanhh@gmail.com ${ }^{1)}$
}

\begin{abstract}
ABSTRAK
Kemajuan teknologi telah mengubah cara perjalanan dan perencanaan kegiatan pariwisata, wisatawan tidak perlu lagi menggunakan alat offline seperti pensil dan kertas untuk mencatat lokasi tempat wisata tertentu. Informasi yang sering ditampilkan adalah informasi tentang tempat wisata, cerita lokal tentang tempat tersebut, informasi akomodasi dan lain sebagainya, wisatawan tidak dapat memperoleh informasi tersebut tanpa bergabung dengan grup wisata atau ponsel dengan akses web. Namun karena keterbatasan informasi tempat wisata dan jarak yang ditempuh atau informasi akomodasi membuat para wisatawan kurang tertarik untuk mengunjungi lokasi objek wisata tersebut. Hal tersebut menyebabkan masyarakat kurang tertarik dengan tempat wisata yang mereka kurang menarik untuk dikunjungi karena kurangnya informasi dan tidak adanya rekomendasi tentang tempat wisata tersebut. Aplikasi sistem informasi yang dibuat dapat membantu aktivitas wisatawan dalam mencari informasi mengenai lokasi wisata, tempat wisata dan lokasi tujuan wisatawan menuju objek wisata, sistem kemudahan dan mobilitas dapat dibangun sistem navigasi pariwisata pada smartphone android, dan metode item Pemfilteran berbasis kolaboratif wisatawan mendapatkan rekomendasi tempat wisata sesuai dengan keinginan pengguna.
\end{abstract}

Keywords : Sistem Informasi, Android, Item-based Collaborative Filtering

\section{I.PENDAHULUAN}

\subsection{Latar Belakang}

Perkembangan teknologi yang terjadi saat ini dapat mempermudah wisatawan dengan memberikan layanan aplikasi informasi dan rekomendasi tempat pariwisata untuk dikunjungi yang terbaru atau up to date dan juga mudah diakses dalam bentuk mobile. Dalam kasus ini tempat pariwisata yang dimaksud berada di Kabupaten Gresik, dimana terdapat berbagai pariwisata yang belum pernah dikunjungi sebelumnya oleh wisatawan baik domestik maupun manca negara. Pariwisata di Kabupaten Gresik sudah memiliki sistem informasi berbasis website yang hanya berisi informasi tentang tempat wisata saja. Tidak adanya sebuah rekomendasi tentang kunjungan tempat wisata, membuat para wisatawan kurang tertarik dengan tempat wisata yang tersedia karena belum adanya review dari wisatawan lain yang pernah berkunjung sebagai referensi tentang tempat wisata tersebut, selain itu juga wisatawan belum mengetahui tempat pariwisata mana yang sering dikunjungi dan paling favorit. Rekomendasi tempat wisata yang dimaksud berupa rating berasal dari wisatawan lainnya yang pernah mengunjungi ke tempat wisata tersebut untuk digunakan sebagai informasi dan referensi kepada wisatawan lainnya tentang tempat wisata yang akan dikunjunginya.

\subsection{Rumusan Masalah}

Berdasarkan latar belakang di atas diambil rumusan masalah yaitu bagaimana penerapan metode item-based collaborative filtering pada sistem informasi aplikasi android wisata di Kabupaten Gresik.

\subsection{Tujuan Penelitian}

Penelitian yang dilakukan bertujuan untuk memberikan informasi pariwisata berbasis aplikasi android.

\subsection{Batasan Masalah}

Pembahasan penulisan ini dibatasi pada ruang lingkup pembahasan sebagai berikut:

a. Aplikasi Android tentang informasi lokasi wisata di di Kabupaten Gresik.

b. Aplikasi ini memanfaatkan Maps Api dari google yang digunakan untuk penentuan wisata dan rute dari posisi user menuju lokasi.

c. Menggunakan metode Adjusted Cosine Similarity untuk menghitung similarity antar pariwisata. 
INDEXIA: Informatic and Computational Intelegent Journal

Hendry Hermawan, Harunur Rosyid

Rancang Bangun Aplikasi Mobile Android Untuk Sistem Informasi Lokasi Wisata Kabupaten Gresik Menggunakan

Metode Item-Based Collaborative Filtering

d. Menggunakan metode Weighted Sum menghitung prediksi rating.

e. Aplikasi dibangun dengan bahasa pemrogaman Java.

f. Perhitungan similarity antar pariwisata mengunakan rating yang diberikan oleh user lain.

\section{LANDASAN TEORI}

\subsection{Sistem informasi}

Sistem informasi yaitu suatu sistem yang menyediakan informasi untuk manajemen dalam mengambil keputusan dan berfungsi untuk menjalankan operasional dalam sebuah perusahaan. Sistem tersebut merupakan kombinasi dari orangorang, teknologi informasi dan prosedur-prosedur yang saling tergorganisasi (Binus University, 2016). Biasanya dalam suatu perusahan atau suatu badan usaha menyediakan semacam informasi yang nantinya berguna bagi manajemen.

Robert A. Leitch, Sistem informasi adalah suatu sistem yang berada di dalam suatu organisasi mempertemukan kebutuhan pengolahan transaksi harian, mendukung sistem operasi, bersifat manajerial dan kegiatan strategi dari suatu organisasi untuk menyediakan pihak luar secara tertentu dengan bentuk laporan-laporan yang diperlukan. Henry Lucas, Kegiatan dari prosedur-prosedur yang diorganisasikan, apabila dieksekusi akan menyediakan sekumpulan informasi untuk mendukung dalam pengambilan keputusan dan pengendalian di dalam. Sistem informasi adalah tipe khusus dari suatu sistem kerja yang dimana manusia dan mesin melakukan pekerjaan secara bersamaan dengan menggunakan sumber daya yang ada untuk memproduksi produk tertentu atau jasa bagi pelanggan (Binus University, 2016).

\subsection{Item-Based Collaborative Filtering}

Metode item-based collaborative filtering digunakan dalam proses penentuan rekomendasi untuk lokasi pariwisata yang nanti sesuai dengan dengan user. Proses penilaian dilakukan mengunakan rating dari tiap lokasi yang nantinya akan di isi atau di nilai oleh user yang sudah berkunjung pada lokasi tersebut. Tahap awal dari metode item-based collaborative filtering adalah menghitung nilai kemiripan diantara tempat pariwisata yang telah dirating oleh user, yang dimana bentuk penilaian dari user sendiri biasanya berupa rating dalam skala tertentu (Sanjoyo, 2009). Untuk proses penghitungan nilai kemiripan antara dua tempat pariwisata, digunakan rumus adjusted-cosine similarity seperti dibawah ini :

$$
\operatorname{sim}(i, j)=\frac{\sum_{u \in U}\left(R_{u, i}-\bar{R}_{u}\right)\left(R_{u, j}-\bar{R}_{u}\right)}{\sqrt{\sum_{u \in U}\left(R_{u, i}-\bar{R}_{u}\right)^{2}} \sqrt{\sum_{u \in U}\left(R_{u, j}-\bar{R}_{u}\right)^{2}}}
$$

Keterangan :

$\operatorname{sim}(i, j)=$ Nilai kemiripan antara tempat pariwisata $\mathrm{i}$ dan tempat pariwisata $\mathrm{j}$.

$\in U \quad=$ Himpunan user $\mathrm{u}$ yang merating tempat pariwisata i dan tempat pariwisata $\mathrm{j}$.

$R(u, i) \quad=$ Rating user $\mathrm{u}$ pada tempat pariwisata $\mathrm{i}$.

$R(u, j) \quad=$ Rating user $\mathrm{u}$ pada tempat pariwisata $\mathrm{j}$.

$\mathrm{Ru} \quad=$ Nilai rata-rata rating user $\mathrm{u}$.

Tahapan selanjutnya yang paling penting dalam proses collaborative filtering adalah pembuatan prediksi. Setelah mendapatkan sekumpulan tempat pariwisata yang sangat mirip berdasarkan perhitungan kemiripan tersebut, dilakukan proses prediksi yang nantinya di proses untuk memperkirakan nilai rating dari user untuk suatu tempat pariwisata yang belum pernah dirating atau didatangi sebelumnya oleh user tersebut.

Teknik yang digunakan untuk mendapatkan nilai prediksi tersebut adalah dengan persamaan weighted sum, teknik ini digunakan untuk memprediksi tempat pariwisata semisal $\mathrm{j}$ untuk user $\mathrm{u}$ dengan menghitung jumlah dari nilai rating yang diberikan oleh user terhadap suatu tempat pariwisata yang berkorelasi dengan tempat pariwisata j. Setiap rating yang diberikan pada tempat pariwisata yang berkorelasi nantinya akan dikalikan dengan nilai kemiripannya (Alfian, 2009). Kemudian dibagi dengan jumlah nilai absolut kemiripan dengan seluruh tempat pariwisata yang berkorelasi. Persamaan weighted sum adalah sebagai berikut:

$$
P_{(u, j)}=\frac{\sum_{i \in I}\left(R_{u . i} * S_{i . j}\right)}{\sum_{i \in I}\left|S_{i . j}\right|}
$$

Keterangan :

$P(u, j)=$ Prediksi untuk user $\mathrm{u}$ pada tempat pariwisata $\mathrm{j}$.

$i \in I=$ Himpunan tempat pariwisata yang mirip dengan tempat pariwisata $\mathrm{j}$.

$R(u, i)=$ Rating user $\mathrm{u}$ pada tempat pariwisata $\mathrm{i}$.

$S(i, j)=$ Nilai kemiripan antara tempat pariwisata $\mathrm{i}$ dan tempat pariwisata $\mathrm{j}$.

Menghitung nilai kemiripan menggunakan nilai yang akan dihasilkan oleh persamaan weighted sum adalah berkisar antara +1.0 dengan -1.0 . Tempat pariwisata diketahui jika nilai kemiripan sama dengan 0 berarti tempat pariwisata tidak berkorelasi (independen). Nilai kemiripan mendekati +1.0 berarti tempat pariwisata cenderung akan mirip antara satu dengan yang lainnya, apabila rating suatu tempat pariwisata telah diketahui maka rating tempat pariwisata yang lainnya dapat diketahui dan disimpulkan dengan probabilitas yang tinggi. Nilai kemiripan mendekati -1.0 berarti tempat pariwisata 
INDEXIA: Informatic and Computational Intelegent Journal

Hendry Hermawan, Harunur Rosyid

Rancang Bangun Aplikasi Mobile Android Untuk Sistem Informasi Lokasi Wisata Kabupaten Gresik Menggunakan

Metode Item-Based Collaborative Filtering

saling bertolak belakang dan dalam kasus ini juga rating suatu tempat pariwisata bisa ditentukan berdasarkan rating dari tempat pariwisata lainnya, tapi keadaannya sekarang apabila rating tempat

\section{BAB III ANALISIS DAN PERANCANGAN SISTEM}

\subsection{Analisis Permasalahan}

Pariwisata merupakan kegiatan perjalanan dimana orang akan berdiam menuju suatu tempat asing untuk maksud tertentu, dan tidak tinggal menetap untuk selama-lamanya atau sementara waktu. Kemajuan dalam hal teknologi telah mengubah cara berpergian dan merencanakan kegiatan pariwisata, wisatawan tidak perlu lagi menggunakan tool offline seperti pensil dan kertas untuk mencatat lokasi obyek wisata tertentu.

Informasi yang sering ditampilkan adalah informasi tempat-tempat wisata, cerita lokal mengenai tempat tersebut, info akomodasi dan sebagainya, wisatawan tidak bisa mendapatkan informasi tersebut tanpa bergabung dengan kelompok tur atau ponsel dengan akses web. Keterbatasan mengenai informasi tempat pariwisata dan jarak yang akan ditempuh atau info akomodasi membuat para wisatawan kurang berminat untuk mengunjungi lokasi obyek wisata tersebut. Penyebab masyarakat kurang berminat terhadap obyek wisata yang menurut mereka tidak menarik dikunjungi karena kurangnya informasi.

Permasalahan tersebut diperlukan suatu sistem yang mampu membantu aktifitas wisatawan dalam mencari informasi mengenai lokasi wisatawan, obyek wisata dan rute tujuan lokasi wisatawan ke obyek wisata, sistem yang mudah dan mendukung mobilitas dapat dibangun sistem navigasi pariwisata pada smartphone android. Mengakses informasi dimanapun berada secara realtime menggunakan perangkat mobile smartphone android bagi wisatawan, karena smartphone android merupakan telepon selular (ponsel) yang mampu selalu terhubung ke internet untuk sinkronisasi data secara otomatis atau manual dan dilengkapi dengan fitur GPS untuk sistem navigasi, tempat menginap serta navigasi untuk membantu para wisatawan untuk menemukan tempat wisata yang terdapat di Kabupaten Gresik.

\subsection{Hasil Analisis}

Berdasarkan analisis yang telah dilakukan, maka terdapat masalah yang dihadapi oleh para wisatawan yang ingin berkunjung ketempat-tempat wisata khususnya tempat wisata yang masih belum pernah dikunjungi sama sekali oleh wisatawan tersebut. Salah satunya kesulitan wisatawan menentukan lokasi tujuan wisata dan bagaimana keadaan wisata ditempat tersebut. Sehingga perlu dibuatnya sebuah aplikasi yang dapat memudahkan para wisatawan untuk dapat menentukan pilihan pariwisata yang seperti apa untuk

pariwisata pertama meningkat maka rating tempat pariwisata kedua justru akan sebaliknya, yaitu menurun.

dikunjungi berdasarkan rekomendasi dari user yang ada pada aplikasi tersebut.

\subsubsection{Flowchart Diagram Aplikasi}

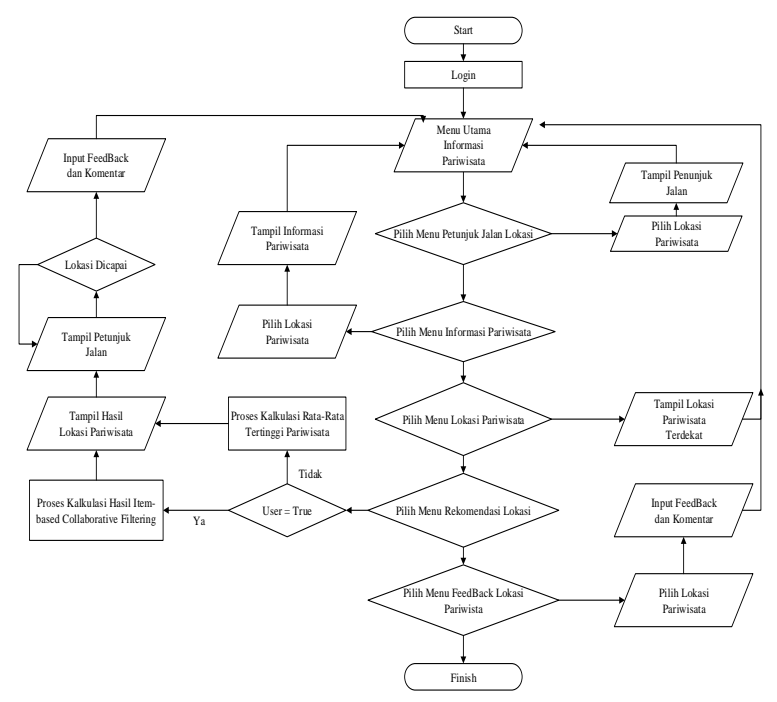

Gambar 3.1 Flowchart Diagram User

User melakukan login mengisikan identitas yang apabila telah selesai melakukan login akan tampil menu utama informasi pariwisata. Informasi pariwisata terdapat lima menu pilihan yang dapat di pilih oleh user yaitu petunjuk jalan lokasi pariwisata, informasi pariwisata, lokasi letak pariwisata, rekomendasi lokasi pariwisata, dan menu feedback lokasi periwisata.

Menu petunjuk jalan lokasi pariwisata digunakan user untuk aplikasi navigasi arah sehingga memudahkan user untuk menemukan jalan menuju lokasi pariwisata dimulai dari memilih pariwisata secara manual dari list yang sudah di sediakan kemudian setelah di pilih akan tampil tampilan navigasi menuju tempat pariwisata. Menu informasi pariwisata yaitu berisi list pariwisata yang disertai dengan penjelasan tenang pariwisata tersebut. Menu lokasi pariwisata yaitu menu yang menampilkan tempat lokasi wisata terdekat dengan user untuk memudahkan pencarian user. Menu rekomendasi lokasi pariwisata digunakan apabila user ingin mendapatkan rekomendasi tempat pariwisata yang sesuai maka sistem akan secara otomastis mencarikan lokasi lokasi pariwisata yang sesuai menggunakan metode item-based collaborative filtering aplikasi kemudian akan tampil list hasil 
INDEXIA: Informatic and Computational Intelegent Journal

Hendry Hermawan, Harunur Rosyid

Rancang Bangun Aplikasi Mobile Android Untuk Sistem Informasi Lokasi Wisata Kabupaten Gresik Menggunakan

Metode Item-Based Collaborative Filtering

rekomendasi sesuai sistem dan apabila user baru mengggunakan rekomendasi akan di tampilkan rata - rata tertinggi dari lokasi pariwisata yang ada, kemudian akan tampil penunjuk jalan menuju tempat pariwisata sesuai dengan hasil tersebut program akan mengulang sampai lokasi tersebut di capai. Lokasi yang telah dicapai oleh wisatawan aplikasi akan menampilkan format feedback yang digunakan user untuk mengisikan komentar tentang lokasi yang sudah dicapai tersebut.

\subsubsection{Flowchart Diagram Admin}

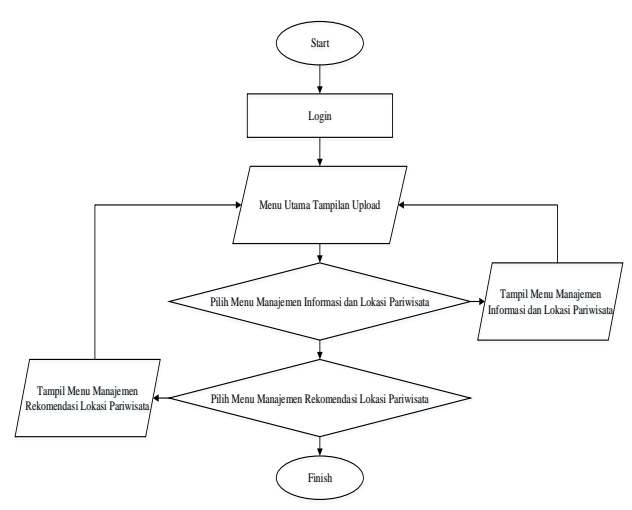

Gambar 3.2 Flowchart Diagram Admin

Admin harus melakukan login user dan password untuk masuk tampilan admin, kemudian akan tampil menu utama admin yang berisi dua menu utama yaitu menu manajemen informasi dan lokasi pariwisata dan yang kedua menu manajemen rekomendasi lokasi pariwisata. Menu manajemen informasi dan lokasi pariwisata di gunakan untuk pengolahan data informasi dan lokasi pariwisata seperti penambahan, pengeditan, dan penghapusan data tentang informasi dan lokasi pariwisata yang akan ditampilkan user. Menu manajemen rekomendasi lokasi wisata digunakan untuk manajemen rekomendasi yang sudah di proses oleh sistem menggunakan metode item-based collaborative filtering, dan pengolahan data seperti halnya penambahan, pengeditan, dan penghapusan data tentang rekomendasi tersebut.

\subsection{Representasi Hasil Analisis}

Dari analisis sistem dilakukan dengan menggunakan flowchart Sistem Rekomendasi Pariwisata Menggunakan Metode Item Based Collaborative Filtering berupa alur data sebagai berikut:

\subsubsection{Use case Diagram Aplikasi}

Langkah pertama yang harus dilakukan untuk menangkap kebutuhan pengguna adalah dengan memodelkan sistem dengan menggunakan use case diagram. Use case diagram menggambarkan ruang lingkup dari sistem yang akan dibangun dan merupakan sarana komunikasi dengan pengguna akhir untuk mendapatkan pemahaman yang lebih baik tentang sistem yang akan dibuat. Komponen - komponen yang terdapat pada sebuah use case diagram terdiri dari:

a. Actor : Pengguna software aplikasi, bisa berupa manusia, hardware, atau sistem informasi yang lain. Actor dapat memasukkan informasi kedalam sistem, menerima informasi dari sistem, atau keduanya.

b. Use case : Apa yang dikerjakan oleh pengguna sistem aplikasi, termasuk interaksi antara actor dengan software aplikasi tersebut.

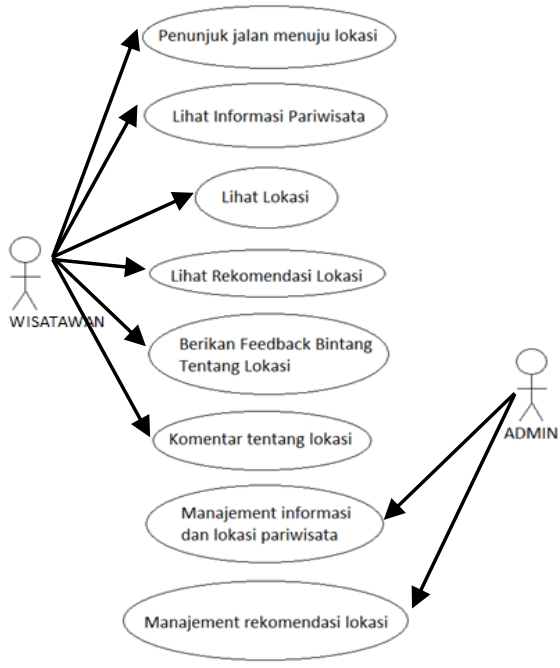

Gambar 3.3 Use Case Diagram

Gambar 3.3 adalah Use Case Diagram rancangan aplikasi yang akan dibuat. Deskripsi dari masing - masing use case dapat dijelaskan sebagai berikut :

\section{User}

a. Use case : Petunjuk jalan menuju lokasi Actor : User dan Sistem

Deskripsi : Use case ini digunakan untuk menampilkan penunjuk arah sesuai lokasi yang telah di tentukan oleh user sesuai dengan rekomendasi lokasi yang telah di tentukan oleh sistem. Rekomendasi yang diperoleh dari feedback mengunakan metode item- 
INDEXIA: Informatic and Computational Intelegent Journal

Hendry Hermawan, Harunur Rosyid

Rancang Bangun Aplikasi Mobile Android Untuk Sistem Informasi Lokasi Wisata Kabupaten Gresik Menggunakan

Metode Item-Based Collaborative Filtering

based collaborative filtering

dari user maupun pemilihan

lokasi secara manual sesuai

list yang di pilih oleh user.

b. Use case : Lihat informasi pariwisata

Actor : User

Deskripsi : Use case ini digunakan untuk menampilkan list informasi lokasi - lokasi pariwisata untuk nantinya dipilih oleh user yang telah tersimpan pada database yang di masukkan oleh admin.

c. Use case : Lihat lokasi

Actor : User

Deskripsi : Use case ini digunakan untuk menampilkan list koordinat lokasi - lokasi pariwisata untuk nantinya dipilih oleh user yang telah tersimpan pada database yang di masukkan oleh admin.

d. Use case : Lihat rekomendasi lokasi Actor : User dan Sistem

Deskripsi : Use case ini digunakan untuk menampilkan list rekomendasi lokasi - lokasi pariwisata untuk dipilih oleh user yang telah di tentukan oleh sistem berdasarkan feedback mengunakan metode item-based collaborative filtering dan yang telah di tentukan oleh admin.

e. Use case : Berikan feedback bintang tentang lokasi

Actor : User dan Sistem

Deskripsi : Use case ini digunakan untuk user mengisi feedback dari tempat lokasi yang telah dikunjungi berdasarkan lokasi - lokasi yang telah di tampilkan, yang nantinya di olah menggunakan metode item-based collaborative filtering untuk nantinya sebagai acuan penentuan rekomendasi lokasi

f. Use case : Komentar tentang lokasi

Actor : User

Deskripsi : Use case ini digunakan untuk user mengisi dari tempat lokasi yang telah dikunjungi berdasarkan lokasi - lokasi yang telah di tampilkan.

\section{Admin}

a. Use case : Manajemen informasi dan lokasi pariwisata

Actor : Admin

Deskripsi : Use case ini digunakan untuk admin menambahkan, mengedit dan menghapus informasi, lokasi, dll yang berada pada database.

b. Use case : Manajemen rekomendasi lokasi

Actor : Admin

Deskripsi : Use case ini digunakan untuk admin menambahkan, mengedit dan menghapus informasi, lokasi, dll yang berada pada database.

\subsubsection{Activity Diagram}

Use Case yang sudah dibuat untuk selanjutnya di lakukan pembuatan activity diagram untuk menjelaskan proses/ aliran yang terjadi pada tiap Use Case. activity diagram adalah salah satu bentuk diagram Unified Modeling Language (UML) yang paling mudah dimengerti dikarenakan diagram ini memiliki simbol yang menyerupai simbol flowchart, yang sangat berguna untuk menjelaskan langkah-langkah proses ke pihak lain. Berikut adalah activity diagram yang digunakan pada aplikasi rekomendasi.

\section{Petunjuk Jalan Menuju Lokasi}

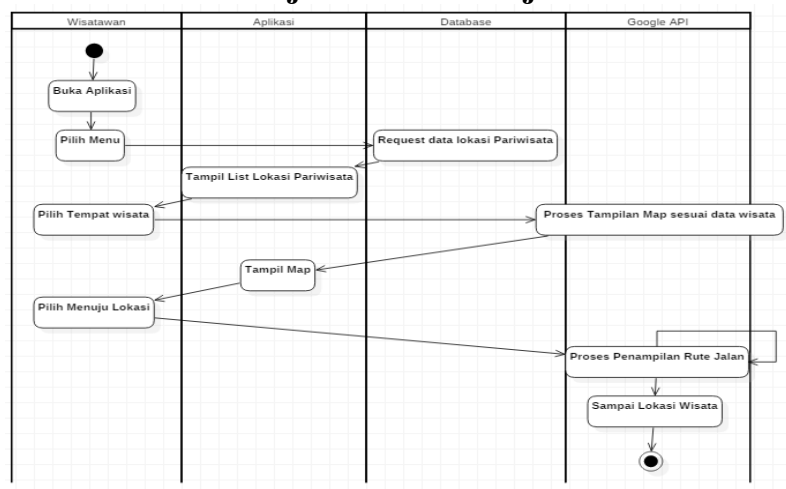

Gambar 3.4 Activity Diagram Petunjuk Jalan Lokasi

Proses dimulai dari wisatawan membuka aplikasi kemudian memilih menu petunjuk jalan menuju lokasi kemudian dari perintah tersebut akan request ke database dan memunculkan tampilan list lokasi pariwisata. Wisatawan memilih tempat pariwisata yang akan dituju, perintah tersebut di request ke google API untuk menampilkan map, kemudian pilih menuju lokasi, google API akan 
INDEXIA: Informatic and Computational Intelegent Journal

Hendry Hermawan, Harunur Rosyid

Rancang Bangun Aplikasi Mobile Android Untuk Sistem Informasi Lokasi Wisata Kabupaten Gresik Menggunakan

Metode Item-Based Collaborative Filtering

terus berulang menunjukkan lokasi yang telah dipilih user sampai tiba di lokasi tersebut.

\section{Lihat Informasi Pariwisata}

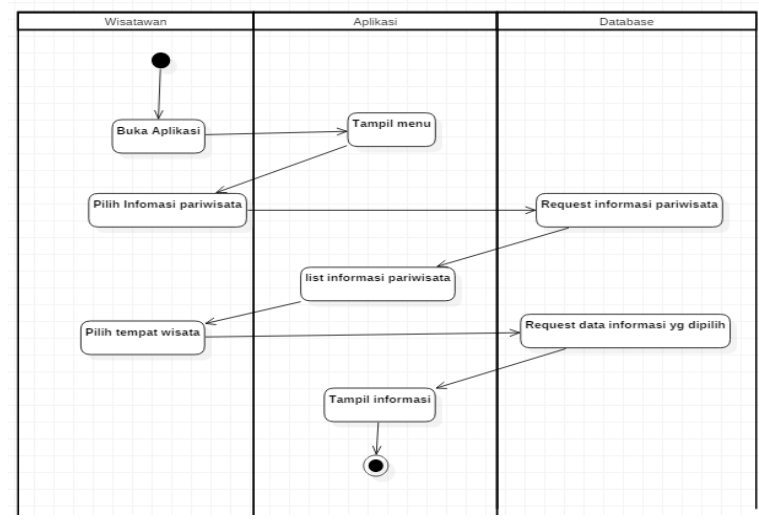

Gambar 3.5 Activity Diagram Lihat Informasi Pariwisata

Proses dimulai dari wisatawan membuka aplikasi kemudian memilih menu informasi pariwisata, kemudian perintah tersebut request ke database dan ditampilkan pada aplikasi berupa list informasi pariwisata setelah itu wisatawan memilih tempat wisata. Saat perintah pemilihan tempat wisata terjadi akan request data informasi yang dipilih, kemudian ditampilkan informasi wisata yang telah dipilih.

\section{Lihat Lokasi Pariwisata}

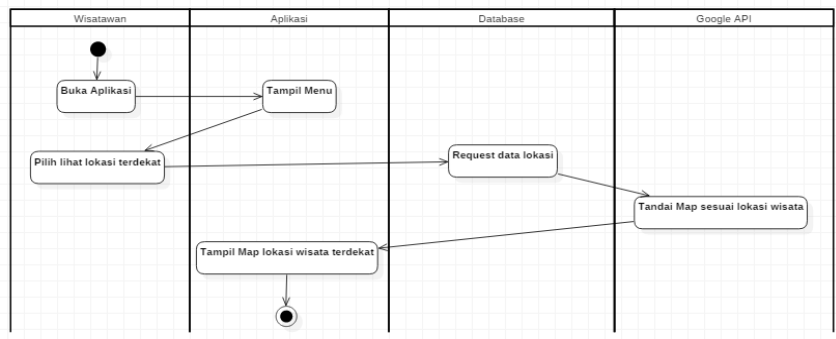

Gambar 3.6 Activity Diagram Lihat Lokasi Pariwisata

Proses dimulai dari wisatawan membuka aplikasi kemudian memilih menu lihat lokasi terdekat. Perintah tersebut akan merequest data pada database kemudian diteruskan pada google API untuk menandai map sesuai data lokasi wisata. Lokasi wisata akan ditampilkan pada aplikasi berupa map lokasi wisata terdekat.

\section{Lihat Rekomendasi Lokasi Pariwisata}

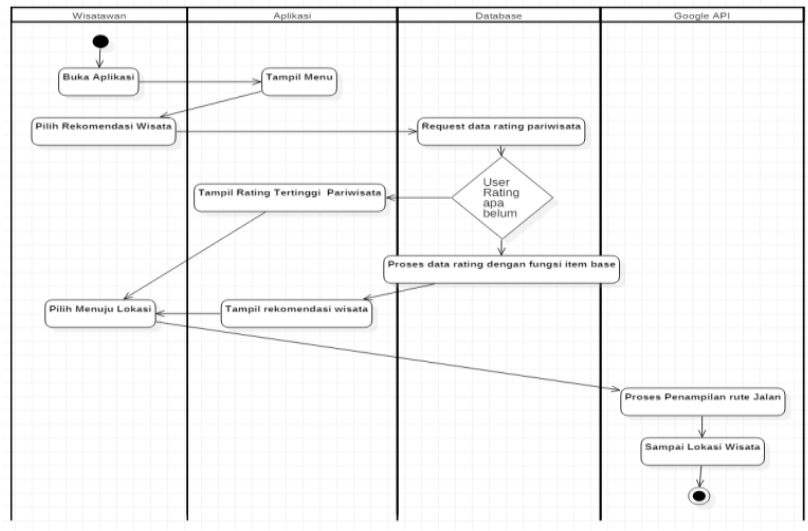

Gambar 3.7 Activity Diagram Rekomendasi Lokasi Pariwisata

Proses dimulai saat wisatawan membuka aplikasi kemudian memilih menu rekomendasi wisata, perintah tersebut akan merequest data rating pariwisata pada database. Data tersebut diolah dengan metode item base collaborative filtering, setelah itu data akan ditampilkan pada aplikasi berupa rekomendasi tempat wisata. User memilih menuju lokasi dan akan ditampilkan berupa map dengan menggunakan google API.

\section{Berikan Feedback Bintang dan Komentar Tentang Lokasi Wisata}

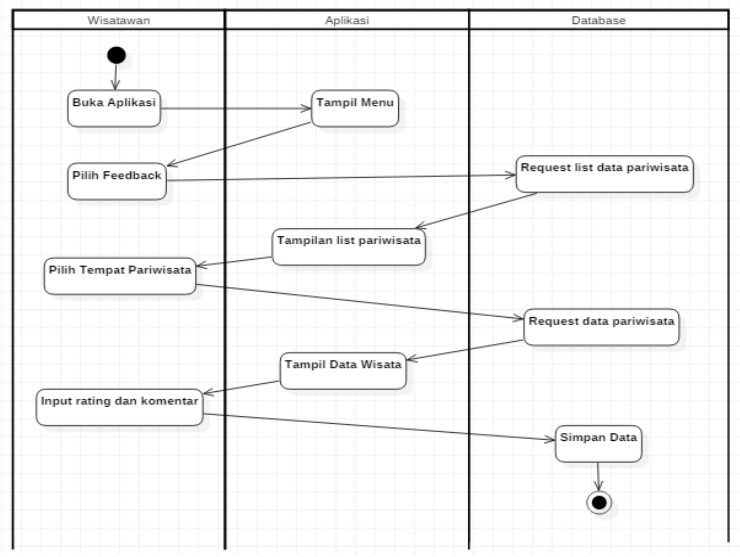

Gambar 3.8 Activity Diagram Feedback Bintang dan Komentar Lokasi Wisata

Proses dimulai saat wisatawan membuka aplikasi kemudian memilih menu feedback. Aplikasi request data pada database data pariwisata kemudian akan menampilkan data pariwisata, user akan memilih salah satu tempat wisata, perintah tersebut request ke google api dan ditampilkan pada aplikasi wisata tersebut. Wisatawan akan menginputkan rating \& komentar kemudian akan di simpan pada database. 
INDEXIA: Informatic and Computational Intelegent Journal

Hendry Hermawan, Harunur Rosyid

Rancang Bangun Aplikasi Mobile Android Untuk Sistem Informasi Lokasi Wisata Kabupaten Gresik Menggunakan Metode Item-Based Collaborative Filtering

\subsection{Perancangan Sistem}

Perancangan berisi rancangan cara kerja dari aplikasi yang nantinya dibuat. Rancangan yang nantinya digunakan dalam pembuatan aplikasi adalah sebagai berikut:

\subsubsection{Rancangan Aplikasi}

Rancangan Aplikasi adalah suatu perencanaan, penggambaran, dan pembuatan alur proses yang berkaitan dan terstruktur dengan berbagai fungsi yang sesuai dengan penerapan konsep yang telah dibuat, agar dapat digunakan untuk melaksanakan dan menjalankan tugas tertentu dalam kegiatan atau aktifitas manusia.

\subsubsection{DFD Level 0 Sistem Informasi}

\section{Pariwisata}

Sistem informasi pariwisata berguna untuk mengelola sebuah objek-objek pariwisata yang ada pada suatu daerah. Dalam perancangan aplikasi sistem informasi pariwisata salah satunya membutuhkan DFD sebagai dasar untuk melihat alur proses sistem aplikasi.

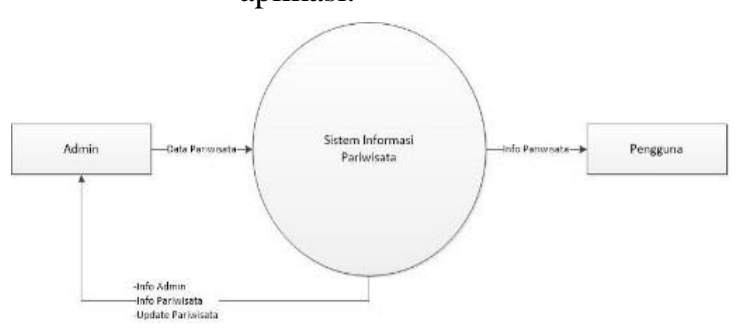

Gambar 3.15 DFD Level 0 Sistem Informasi Pariwisata

\subsubsection{DFD Level 1 Sistem Informasi} Pariwisata

Untuk user atau pengguna aplikasi ini, ada 2 yaitu admin dan pengunjung dengan rinciannya sebagai berikut:

1. Admin, merupakan operator aplikasi yang mengentri data pariwiata pada aplikasi sistem informasi pariwisata

2. Pengunjung, merupakan pengunjung aplikasi web sistem informasi pariwisata yang memungkinkan untuk mendapatkan informasi tentang pariwisata yang ada pada aplikasi sistem informasi pariwisata

Data yang masuk kedalam sistem:
1. Admin yaitu data pariwisata

Data yang keluar dari sistem:

1. Admin yaitu data admin, data pimpinan, data pariwisata

2. Pengunjung yaitu data pariwisata

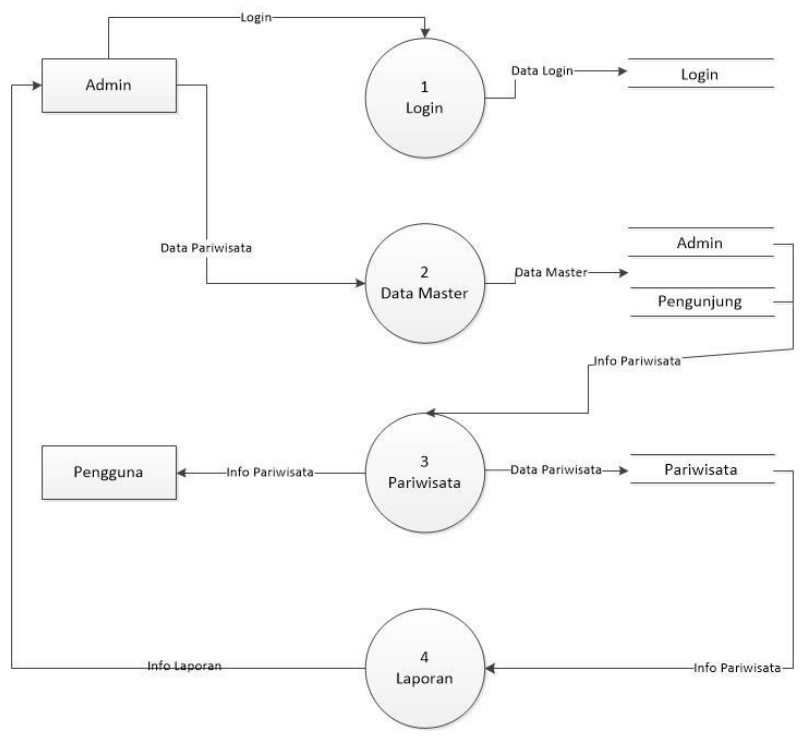

Gambar 3.16 DFD Level 1 Sistem Informasi Pariwisata

\section{BAB IV IMPLEMENTASI DAN PENGUJIAN SISTEM}

\subsection{Implementasi}

Implementasi antar muka ini akan dijelaskan fitur-fitur dan fungsi-fungsi yang terdapat dalam perangkat lunak sesuai dengan perancangan sistem yang telah dibuat sebelumnya. Implementasi antar muka dibuat untuk menjadi penghubung antara pengguna dan sistem. Implementasi antar muka ini berupa aplikasi pada android.

\subsubsection{Tampilan Awal}

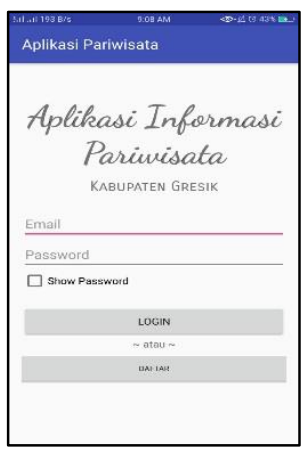

\section{Gambar 4.1 Tampilan Awal Aplikasi}

Tampilan awal merupakan tampilan ketika user membuka aplikasi pertama kali. Pada tugas akhir ini menggunakan xampp sebagai server. Desain aplikasi dibuat sesimpel mungkin agar user mudah 
INDEXIA: Informatic and Computational Intelegent Journal

Hendry Hermawan, Harunur Rosyid

Rancang Bangun Aplikasi Mobile Android Untuk Sistem Informasi Lokasi Wisata Kabupaten Gresik Menggunakan

Metode Item-Based Collaborative Filtering

menggunakannya. Tampilan awal terdapat form login dengan memasukkan email dan password, apabila belum mempunyai akun untuk login maka klik daftar untuk mendaftarkan email, saat di klik tombol login akan masuk pada menu utama.

\subsubsection{Tampilan Menu Daftar

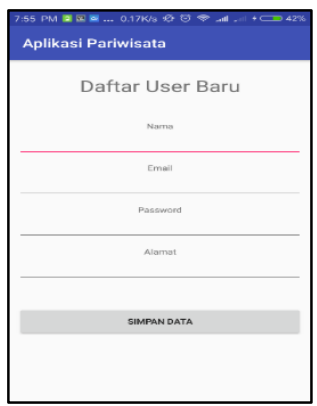

Gambar 4.3 Tampilan Menu Daftar

User wisatawan yang belum mempunyai akun untuk login, maka diharuskan untuk mendaftar terlebih dahulu sebelum memasuki aplikasi. Tampilan pada menu daftar terdapat 4 kolom yang harus di isi oleh user wisatawan yaitu nama, email, password, dan alamat. Kemudian data user tersebut akan disimpan pada database.

\subsubsection{Tampilan Menu Utama}

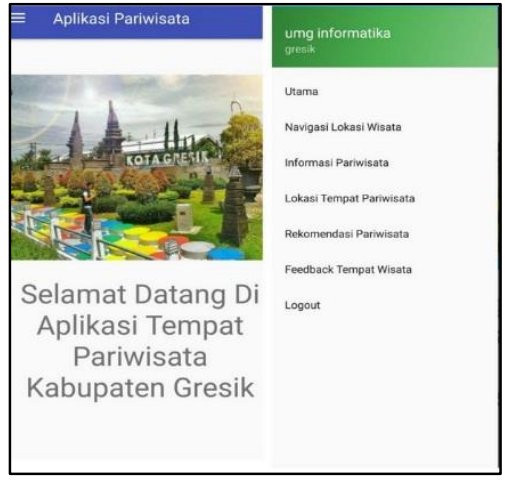

Gambar 4.5 Menu Aplikasi

Form menu utama merupakan form yang ditampilkan jika user telah memulai aplikasi dengan benar. Form ini terdiri dari beberapa menu yang digunakan sebagai aktifitas didalam aplikasi ini. Form menu utama berisi menu utama, navigasi lokasi wisata, informasi pariwisata, lokasi tempat pariwisata, rekomendasi pariwisata, feedback tempat wisata, dan logout. Menu utama cukup simple dengan tulisan selamat datang, untuk melihat menu-menu yang tersedia touch pada pojok kiri atas kemudian akan muncul tampilan beberapa menu yang terdapat pada aplikasi pariwisata ini.

\subsubsection{Navigasi Lokasi Wisata}

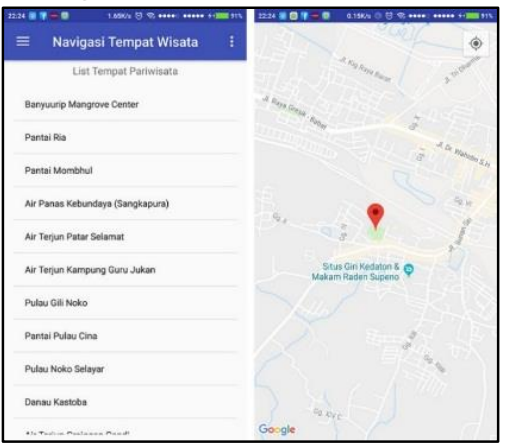

Gambar 4.7 Menu Navigasi Lokasi Wisata

Fitur pada menu navigasi lokasi wisata terdapat list tempat-tempat wisata yang terdapat pada Kabupaten Gresik, setelah memilih salah salah satu tempat wisata akan otomatis masuk ke google map dan mengarahkan user wisatawan menuju lokasi wisata yang dituju. Fitur ini akan sangat membantu para wisatawan yang tidak mengetahui arah tujuan ketika dia akan mengunjungi sebuah lokasi.

\subsubsection{Informasi Pariwisata}

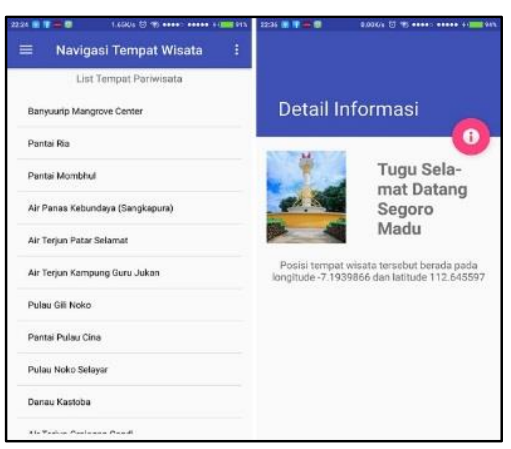

Gambar 4.10 Menu Informasi Pariwisata

Menu informasi pariwisata terdapat informasi mengenai lokasi yang dipilih dalam list tempat wisata. Informasi yang tampil berupa gambar dan penjelasan mengenai wisata tersebut, berikut adalah script untuk menu list pariwisata informasi pariwisata dan menu informasi pariwisata. 
4.1.6 Tampilan Lokasi Tempat Pariwisata

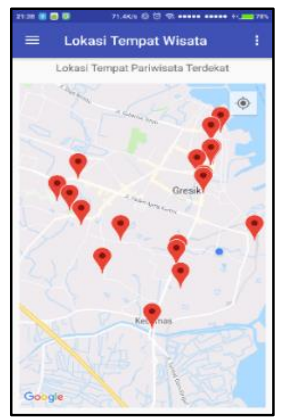

Gambar 4.13 Menu Lokasi Tempat Pariwisata

Menu lokasi tempat pariwisata maka akan langsung masuk pada google map. Menu lokasi tempat wisata akan tampil tanda pada tempat-tempat wisata yang terdapat pada list.

\subsubsection{Tampilan Rekomendasi Pariwisata}

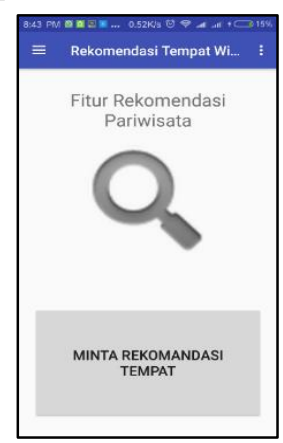

Gambar 4.15 Menu Rekomendasi Pariwisata

Menu rekomendasi pariwisata akan muncul tempat-tempat hasil rekomendasi oleh wisatawan lain yang telah berkunjung. Rekomendasi didapatkan dari perhitungan item-based collaborative filtering berdasarakan hasil rating dan feedback.

\subsubsection{Tampilan Feedback Tempat Wisata}

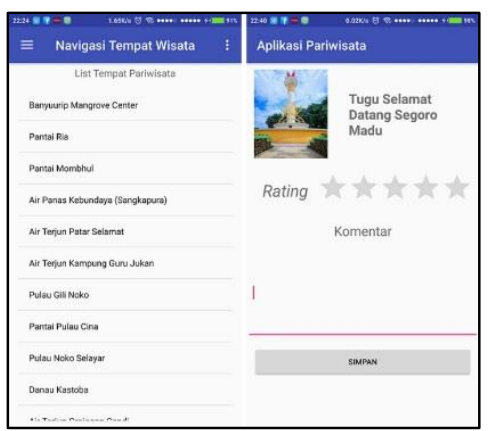

Gambar 4.17 Menu Feedback Tempat Wisata
Wisatawan yang telah berkunjung dan menikmati tempat wisata tersebut dapat meninggalkan komentar feedback dari tempat wisata tersebut dan memberikan rating. Rating dan komentar yang sudah di isikan akan disimpan kedalam database.

\subsection{Pengujian Sistem}

4.2.1 Uji Coba Fungsi Aplikasi

Uji coba ini bertujuan untuk mengetahui apakah sistem yang dibuat dapat berjalan dengan benar sesuai dengan fungsi-fungsinya. Uji coba yang dilakukan berisi pengecekan fungsional aplikasi.

Tabel 4.1 Pengecekan Fungsional Aplikasi Pariwisata

\begin{tabular}{|c|c|c|c|c|}
\hline No & Tujuan & Input & $\begin{array}{l}\text { Output yang } \\
\text { diharapkan }\end{array}$ & Hasil \\
\hline 1 & $\begin{array}{l}\text { Menampilkan } \\
\text { peta digital } \\
\text { beserta lokasi } \\
\text { wisatawan, } \\
\text { tempat, tandai } \\
\text { lokasi yang } \\
\text { berasal dari } \\
\text { database } \\
\text { server }\end{array}$ & $\begin{array}{l}\text { Pilih } \\
\text { Navigasi } \\
\text { kota } \\
\text { wisata }\end{array}$ & $\begin{array}{l}\text { Peta digital } \\
\text { beserta lokasi } \\
\text { wisatawan, } \\
\text { tempat, tandai } \\
\text { lokasi }\end{array}$ & Sesuai \\
\hline 2 & $\begin{array}{l}\text { Menampilkan } \\
\text { Informasi } \\
\text { tentang suatu } \\
\text { tempat wisata } \\
\text { yang di pilih } \\
\text { yang berasal } \\
\text { dari database } \\
\text { server }\end{array}$ & $\begin{array}{l}\text { Pilih salah } \\
\text { satu } \\
\text { tempat } \\
\text { wisata } \\
\text { pada } \\
\text { menu } \\
\text { Informasi } \\
\text { Pariwisata }\end{array}$ & $\begin{array}{l}\text { Informasi } \\
\text { berupa } \\
\text { gambar, teks } \\
\text { dan berisi } \\
\text { penjelasan } \\
\text { lengkap }\end{array}$ & Sesuai \\
\hline 3 & $\begin{array}{l}\text { Memperoleh } \\
\text { rekomendasi } \\
\text { tempat wisata } \\
\text { sesuai } \\
\text { feedback dari } \\
\text { user lain yang } \\
\text { telah } \\
\text { berkunjung } \\
\text { yang berasal } \\
\text { dari database } \\
\text { server }\end{array}$ & $\begin{array}{l}\text { Pilih } \\
\text { menu } \\
\text { Rekomen } \\
\text { dasi } \\
\text { Pariwisata }\end{array}$ & $\begin{array}{l}\text { Memperoleh } \\
\text { rekomendasi } \\
\text { suatu tempat } \\
\text { wisata dari } \\
\text { feedback yang } \\
\text { di akumulasi } \\
\text { oleh user lain }\end{array}$ & Sesuai \\
\hline
\end{tabular}


INDEXIA: Informatic and Computational Intelegent Journal

Hendry Hermawan, Harunur Rosyid

Rancang Bangun Aplikasi Mobile Android Untuk Sistem Informasi Lokasi Wisata Kabupaten Gresik Menggunakan Metode Item-Based Collaborative Filtering

\begin{tabular}{|c|c|c|c|c|}
\hline 4 & $\begin{array}{l}\text { Menambahka } \\
\text { n komentar } \\
\text { dan rating } \\
\text { pada suatu } \\
\text { tempat wisata } \\
\text { yang nantinya } \\
\text { tersimpan } \\
\text { pada database } \\
\text { server }\end{array}$ & $\begin{array}{l}\text { Pilih salah } \\
\text { satu } \\
\text { wisata, } \\
\text { tulis } \\
\text { komentar } \\
\text { tentang } \\
\text { tempat } \\
\text { wisata yg } \\
\text { dikunjung } \\
\text { i dan } \\
\text { berikan } \\
\text { rating }\end{array}$ & $\begin{array}{l}\text { Menyimpan } \\
\text { feedback dari } \\
\text { user berupa } \\
\text { komentar dan } \\
\text { rating }\end{array}$ & Sesuai \\
\hline 5 & $\begin{array}{l}\text { Mendapatkan } \\
\text { rekomendasi } \\
\text { dari metode } \\
\text { Item-Based } \\
\text { Collaborative } \\
\text { Filtering yang } \\
\text { berasal dari } \\
\text { database } \\
\text { server }\end{array}$ & $\begin{array}{l}\text { Pilih } \\
\text { menu } \\
\text { Rekomen } \\
\text { dasi } \\
\text { Pariwisata }\end{array}$ & $\begin{array}{l}\text { Mendapatkan } \\
\text { Rekomendasi } \\
\text { tempat wisata } \\
\text { dari feedback } \\
\text { wisatawan } \\
\text { lain yang } \\
\text { berkunjung } \\
\text { dengan } \\
\text { menerapkan } \\
\text { metode Item- } \\
\text { Based } \\
\text { Collaborative } \\
\text { Filtering }\end{array}$ & Sesuai \\
\hline
\end{tabular}

\subsection{Pengujian Sistem Rekomendasi Aplikasi Sistem}

Sistem rekomendasi berjalan dengan baik dan menampilkan rekomendasi sesuai dengan perhitungan manual, pengujian dilakukan dengan menambahkan user baru kemudian user tersebut melakukan feedback salah satu pariwisata, setelah selesai melakukan feedback user baru tersebut meminta rekomendasi tempat wisata menggunakan aplikasi pariwisata yang dibuat. Hasil rekomendasi yang di tampilkan aplikasi kemudian di bandingkan dengan hasil perhitungan rekomendasi secara perhitungan manual untuk memastikan apakah sistem rekomendasi sesuai dengan perhitungan manual atau tidak. Pengujian ini menggunakan data rating dari 2 user sebelumnya yang sudah melakukan rating kepada 5 tempat wisata yang sudah ada. Tahapan proses pengujian sistem rekomendasi adalah sebagai berikut.

Pertama pengecekan user pada table user untuk memastikan user baru yang akan daftar masuk kedalam tabel user. Data akan ditampilkan dalam bentuk tabel menggunakan program database.

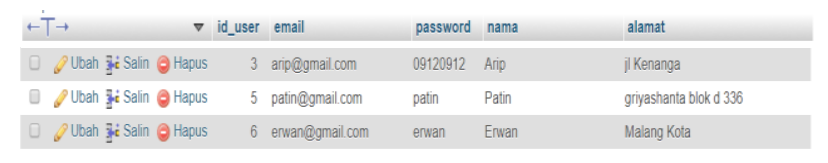

Gambar 4.20 Data Tabel User

Aplikasi akan dilakukan penambahan user baru dengan cara menekan tombol daftar untuk menjadi user baru. Kemudian user melakukan login untuk masuk kedalam aplikasi pariwisata.

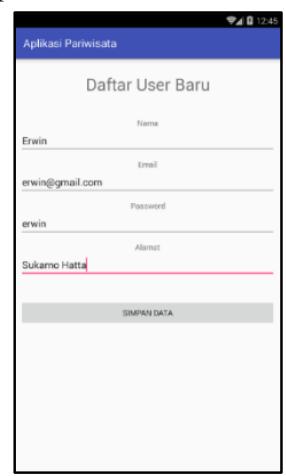

Gambar 4.21 User Baru Mengisi Data Daftar User Baru

Gambar 4.21 User baru mengisi data yang nantinya di tambahakan setelah itu user baru menekan tombol simpan data. Data user baru tersebut akan tersimpan ke dalam database pada tabel user.

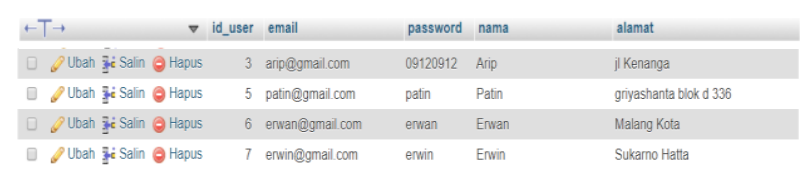

Gambar 4.22 Data Tabel User Setelah Ditambah Data

Gambar 4.22 menunjukan bahwa user baru telah tersimpan pada tabel user. User baru dilakukan login aplikasi untuk menambahakan feedback bintang dan komentar pada salah satu tempat pariwisata.

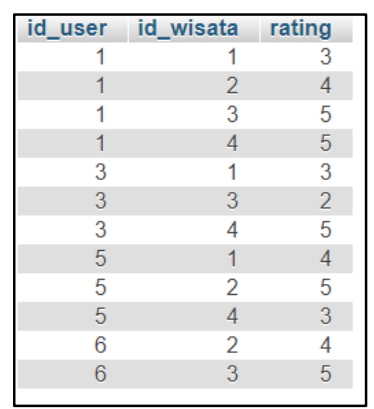

Gambar 4.23 Data Tabel Rating

\begin{tabular}{|rrl|}
\hline id_user & id_wisata & komentar \\
3 & 3 & gas lah bagus \\
3 & 4 & Bagus lah \\
3 & 1 & nice lur \\
1 & 1 & bagus bro \\
1 & 4 & nice lah bro \\
5 & 2 & bagus banget \\
5 & 1 & apik pisan uy \\
6 & 3 & Nice pisan uy \\
\hline
\end{tabular}

Gambar 4.24 Data Tabel Komentar 
INDEXIA: Informatic and Computational Intelegent Journal

Hendry Hermawan, Harunur Rosyid

Rancang Bangun Aplikasi Mobile Android Untuk Sistem Informasi Lokasi Wisata Kabupaten Gresik Menggunakan Metode Item-Based Collaborative Filtering

Gambar 4.23 dan Gambar 4.24 menunjukan bahwa isi data sebelum adanya penambahan feedback rating dan komentar dari user baru. Data diambil dari database yang ditampilkan dalam bentuk tabel.

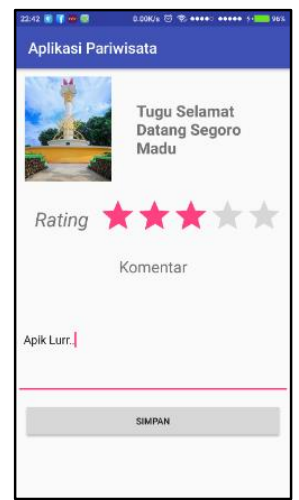

Gambar 4.25 User Baru Menambahkan Feedback Baru

Gambar 4.25 menunjukan user baru mengisikan rating dan komentar baru. Data akan disimpan kedalam database tabel rating dan komentar dengan menekan tombol simpan pada aplikasi.

\begin{tabular}{|rrl|}
\hline id_user & id_wisata & komentar \\
3 & 3 & gas lah bagus \\
3 & 4 & Bagus lah \\
3 & 1 & nice lur \\
1 & 1 & bagus bro \\
1 & 4 & nice lah bro \\
5 & 2 & bagus banget \\
5 & 1 & apik pisan uy \\
6 & 3 & Nice pisan uy \\
7 & 1 & bagus nice place \\
\hline
\end{tabular}

Gambar 4.26 Data Tabel Komentar Setelah Ditambah Data

\begin{tabular}{|rrr|}
\hline id_user & id_wisata & rating \\
1 & 1 & 3 \\
1 & 2 & 4 \\
1 & 3 & 5 \\
1 & 4 & 5 \\
3 & 1 & 3 \\
3 & 3 & 2 \\
3 & 4 & 5 \\
5 & 1 & 4 \\
5 & 2 & 5 \\
5 & 4 & 3 \\
6 & 2 & 4 \\
6 & 3 & 5 \\
7 & 1 & 4 \\
\hline
\end{tabular}

Gambar 4.27 Data Tabel Rating Setelah Ditambah Data

Gambar 4.26 dan Gambar 4.27 menunjukan bahwa data yang di simpan user baru telah tersimpan pada tabel rating dan komentar. User baru menggunakan fitur rekomendasi wisata untuk mendapatkan rekomendasi tempat yang perhitungannya menggunakan fitur item based collaborative filtering yang dibuat pada sistem aplikasi yang nantinya hasil tersebut dibandingkan dengan hasil perhitungan manual.

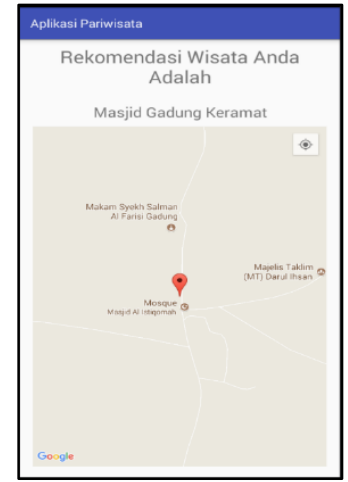

Gambar 4.28 Hasil Rekomendasi Tempat Wisata Menurut Sistem

Gambar 4.28 menunjukan hasil rekomendasi tempat pariwisata yang telah dihitung oleh sistem yang menunjukkan tempat rekomendasinya adalah "Masjid Gadung Keramat" untuk selanjutnya dibandingkan dengan perhitungan manual untuk memastikan hasil rekomendasi sesuai atau tidak. Perhitungan data rating yang berada di database saya pindah dalam tabel untuk memudahkan perhitungan. Tabel rating terdapat paling banyak 4 lokasi wisata yang sudah di feedback oleh user lain karena itu pada tabel berikut hanya menggunakan 4 lokasi wisata.

Tabel 4.4 Rating Feedback User

\begin{tabular}{|c|c|c|c|c|c|}
\hline \multirow{2}{*}{$\begin{array}{c}\text { Nama } \\
\text { User }\end{array}$} & $\begin{array}{c}\text { Makam } \\
\text { Sunan Giri }\end{array}$ & $\begin{array}{c}\text { Pantai } \\
\text { Dalegan }\end{array}$ & $\begin{array}{c}\text { Makam } \\
\text { Maulana } \\
\text { Malik } \\
\text { Ibrahim }\end{array}$ & $\begin{array}{c}\text { Pantai } \\
\text { Ria }\end{array}$ & $\begin{array}{c}\text { Rata } \\
\text { rata }\end{array}$ \\
\cline { 2 - 6 } & $\mathbf{1}$ & $\mathbf{2}$ & $\mathbf{3}$ & $\mathbf{4}$ & \\
\hline Devri & 3 & 4 & 5 & 5 & 4,25 \\
\hline Arip & 3 & - & 2 & 5 & 3.33 \\
\hline Patin & 4 & 5 & - & 3 & 4 \\
\hline Erwan & - & 4 & 5 & - & 4,5 \\
\hline Erwin & 4 & - & - & - & 4 \\
\hline
\end{tabular}

digunakan rumus sesuai dengan rumus 2.1 yang berada pada bab II untuk menentukan kesamaan antara satu pariwisata dengan pariwisata lain. Perhitungan kesamaan antara satu pariwisata dengan pariwisata lain adalah sebagai berikut :

$$
\begin{gathered}
\operatorname{sim}(1,2)=\frac{(3-4.25)(4-4.25)+(4-4)(5-4)}{\sqrt{(3-4.25)^{2}+(4-4)^{2}} \sqrt{(4-4.25)^{2}+(5-4)^{2}}} \\
\operatorname{sim}(1,2)=\frac{0.3175}{1.2884}=0.24
\end{gathered}
$$

$\operatorname{sim}(1,3)$

$$
=\frac{(3-4.25)(5-4.25)+(3-3.33)(2-3.33)}{\sqrt{(3-4.25)^{2}+(3-3.33)^{2}} \sqrt{(5-4.25)^{2}+(2-3.33)^{2}}}
$$


INDEXIA: Informatic and Computational Intelegent Journal

Hendry Hermawan, Harunur Rosyid

Rancang Bangun Aplikasi Mobile Android Untuk Sistem Informasi Lokasi Wisata Kabupaten Gresik Menggunakan Metode Item-Based Collaborative Filtering

$$
\operatorname{sim}(1,3)=\frac{-0.4986}{1.9760}=-0.25
$$

$$
\begin{gathered}
\operatorname{sim}(1,4) \\
=\frac{(3-4.25)(5-4.25)+(3-3.33)(5-3.33)+(4-4)(3-4)}{\sqrt{(3-4.25)^{2}+(3-3.33)^{2}+(4-4)^{2}} \sqrt{(5-4.25)^{2}+(5-3.33)^{2}(3-4)^{2}}} \\
\operatorname{sim}(1,4)=\frac{-1.4886}{2.4957}=-0.59
\end{gathered}
$$

$$
P_{(e r w i n, w 4)}=\frac{(4 *-0.44)+(0 *-0.92)+(0 *-0.59)}{|-0.44|+|-0.92|+|-0.59|}
$$

$$
P_{(e r w i n, w 4)}=\frac{-1.76}{1.95}=-0.9
$$

Perhitungan diatas didapatkan hasil sebagai berikut, wisata 2 yaitu Pantai Dalegan mempunyai nilai pediksi 0.44 , kemudian wisata 3 yaitu Makam Maulana Malik Ibrahim mempunyai nilai pediksi -0.54 dan wisata 4 yaitu Pantai Ria mempunyai nilai pediksi -0.9. Dari hasil perhitungan diatas, nilai prediksi yang mendekati satu akan dijadikan rekomendasi pariwisata kepada user baru yaitu wisata 2 Pantai Dalegan dengan nilai prediksi 0,24 . Hasil perhitungan rekomendasi dari sistem dan rekomendasi dari hitungan manual berarti sama dan sesuai.

$$
\begin{gathered}
\operatorname{sim}(2,4)=\frac{(4-4.25)(5-4.25)+(5-4)(3-4)}{\sqrt{(4-4.25)^{2}+(5-4)^{2}} \sqrt{(5-4.25)^{2}+(3-4)^{2}}} \\
\operatorname{sim}(2,4)=\frac{-1.19}{1.2883}=-0,92
\end{gathered}
$$

$$
\begin{gathered}
=\frac{\operatorname{sim}(3,4)}{\sqrt{(5-4.25)^{2}+(2-3.33)^{2}} \sqrt{(5-4.25)^{2}+(5-3.33)^{2}}} \\
\operatorname{sim}(3,4)=\frac{-1.6586}{2.7981}=-0,59
\end{gathered}
$$

Hasil perhitungan dari rumus akan disimpan untuk proses perhitungan selanjutnya . Tabel kesamaan nilai antar tempat wisata akan ditampilkan berikut.

Tabel 4.5 Adjusted Cosine Pariwisata

\begin{tabular}{|c|c|c|}
\hline & & Nilai Kemiripan \\
\hline Wisata 1 & Wisata 2 & 0.24 \\
\hline Wisata 1 & Wisata 3 & -0.25 \\
\hline Wisata 1 & Wisata 4 & -0.59 \\
\hline Wisata 2 & Wisata 3 & -0.99 \\
\hline Wisata 2 & Wisata 4 & -0.92 \\
\hline Wisata 3 & Wisata 4 & -0.59 \\
\hline
\end{tabular}

Tabel 4.5 adalah hasil perhitungan dari rumus adjusted cosine selanjutnya akan dilakukan perhitungan prediksi rekomendasi dengan rumus weighted sum. Berikut perhitungan prediksi rekomendasi lokasi pariwisata untuk user baru menggunakan persamaan weighted sum sesuai dengan rumus 2.2 yang berada pada bab II.

$$
\begin{gathered}
P_{(e r w i n, w 2)}=\frac{(4 * 0.24)+(0 *-0.99)+(0 *-0.92)}{|0.24|+|-0.99|+|-0.92|} \\
P_{(e r w i n, w 2)}=0.44 \\
P_{(e r w i n, w 3)}=\frac{(4 *-0.25)+(0 *-0.99)+(0 *-0.59)}{|-0.25|+|-0.99|+|-0.59|} \\
P_{(e r w i n, w 3)}=\frac{-1}{1.83}=-0.54
\end{gathered}
$$

\section{BAB V PENUTUP}

\subsection{Kesimpulan}

Perancangan sistem dan pembuatan aplikasi

Sistem Informasi Lokasi Wisata Kabupaten Gresik Mengunakan Metode Item-Based Collaborative Filtering berbasis android ini dilakukan dari evaluasi hasil penelitiannya. Aplikasi sistem informasi juga dilakuan pengujian fungsional sehingga dapat diambil kesimpulan sebagai berikut:

1. Server digunakan sebagai penyimpanan database aplikasi sistem informasi dapat menampilkan informasi pariwisata tanpa harus memperbaharui aplikasi pariwisata.

2. Informasi dapat terupdate secara langsung aplikasi pariwisata mengakses service yang ada pada server untuk mengakses database yang dimana proses pembaharuan, pengeditan, dan penyimpanan melalui database yang tersimpan pada server.

3. Rating dari user yang telah merating tempat pariwisata dapat dicari kesamaan antar pariwisata menggunakan rumus adjusted cosine similarity setelah diketahui kesamaan kemudian dilanjutkan dengan perhitungan menggunakan rumus weighted sum untuk mencari nilai prediksi rekomendasi sehingga dari nilai prediksi rekomendasi tersebut nilai tertinggi dijadikan rekomendasi untuk user.

4. Sistem aplikasi memudahkan wisatawan dalam melihat obyek wisata beserta komponennya yang dipandu dengan arah rute tujuan dan rute terpendek dimana informasi yang disajikan berupa peta digital, mengetahui posisi keberadaannya, dan mengetahui posisi tempat-tempat wisata.

5. Penggunaan metode item-based collaborative filtering memudahkan wisatawan untuk mendapatkan rekomendasi tempat wisata sesuai dengan apa yang diinginkan wisatawan tersebut.

6. Dapat diketahui dari kuesioner penelitian nilai kejelasan, kemudahan, kepuasan, hingga kemanfaatan pada aplikasi yang terdapat pada lampiran memperoleh nilai secara keseluruhan dengan menggunakan perhitungan Skala Likert 
INDEXIA: Informatic and Computational Intelegent Journal

Hendry Hermawan, Harunur Rosyid

Rancang Bangun Aplikasi Mobile Android Untuk Sistem Informasi Lokasi Wisata Kabupaten Gresik Menggunakan

Metode Item-Based Collaborative Filtering

yaitu sebesar 55\% yang dimana nilai tersebut masuk dalam kategori hasil persentasi nilai yang cukup baik.

\subsection{Saran}

Berdasarkan uraian hasil analisis terdapat beberapa kekurangan pada sistem ini, penulis memberikan saran sebagai berikut:

1. Sistem ini dapat dikembangkan untuk berbagai jenis platform smartphone.

2. Data tempat pariwisata perlu diperbanyak.

3. User interface dapat diperbagus lagi agar lebih menarik bagi user.

\section{DAFTAR PUSTAKA}

Akhiro, R. 2008. Studi Multi Criteria Decision Making (MCDM) untuk Recommender System Bursa Tenaga Kerja. Tesis. Institut Teknologi Bandung: Bandung.

Alfian, G. 2009. Rancang Bangun Sistem Rekomendasi Buku Menggunakan Collaborative Filtering. Skripsi. UIN Sunan Kalijaga: Yogyakarta.

Android. 2017.

About

Android. http://www.android.com/about/. diakses 26 Juli 2017.
Android. 2017. History Android. https://www.android.com/intl/id_id/history/\#. diakses 27 Juli 2017.

Android. 2017. Developer Android. http://developer.android.com/guide /basics/what-is-android.html. diakses 27 Juli 2017.

$\begin{array}{lll}\text { Android } & \text { Studio. } & 2017 .\end{array}$ https://developer.android.com/studio/intro/ index.html. diakses 30 Juli 2017.

Binus University. 2016. Pengertian Sistem Informasi. http://scdc.binus.ac.id/ himsisfo/2016/07/pengertian-sistem-informasi/. diakses 30 Juli 2917.

MySQL. 2017.2 About Mysql. https://www.mysql.com/about/. diakses 30 Juli 2017

Sanjoyo, P. 2009. Pembangunan Perangkat Lunak Sistem Rekomendasi Bursa Elektronis Telepon Genggam. Tesis. Insitut Teknologi Bandung: Bandung.

Schafer,J.B., Frankowski, D.,Herlocker,J.dan Sen, S. 2007. Collaborative Filtering Recommender System. Springer-Verlag, Berlin, Heidelberg, tersedia

http:/www.inf.unibbz.it/ ricci/ATIS/index.html. 